\title{
Rudimentary small upper premolars in the Northern bat, Eptesicus nilssoni (Vespertilionidae, Chiroptera)
}

\author{
Tatyana V. Fadeeva \& Sergei V. Kruskop
}

\begin{abstract}
A case of presence of the upper small premolar in the genus Eptesicus is being described. Members of this genus were thought to be invariable in having no small premolars in upper toothrows. However, nine partial skulls of northern bats with traces of upper small premolars were excavated from cave deposits of Perm' Territory. One additional specimen with abnormal dental formula was found in the collection of the Zoological Moscow of Moscow University. The presence of the small premolars in at least some individuals represents a primitive trait which puts $E$. nilssoni apart from the more advanced members of its genus.
\end{abstract}

KEY WORDS: Eptesicus, northern bat, tooth formula, small premolar, cave deposits.

Tatyana V. Fadeeva [fadeeva.tatyana@mail.ru], Institute of Plant and Animal Ecology of RAS Ural Branch, ul. 8th of March 202, Ekaterinburg 620144, Russia; Sergei V. Kruskop [kruskop@zmmu.msu.ru], Zoological Museum, Moscow State University, ul. Bolshaya Nikitskaya 6, Moscow 125009, Russia.

\section{Рудиментарные верхние малые предкоренные зубы у северного кожанка, Eptesicus nilssoni (Vespertilionidae, Chiroptera)}

\section{Т.В. Фадеева, С.В. Крускоп}

\begin{abstract}
РЕЗЮМЕ. Описывается случай наличия верхних малых предкоренных зубов у представителя рода Eptesicus. Предполагалось, что у видов этого рода малых предкоренных в верхнем зубном ряду не бывает никогда. Однако в пещерных отложениях Пермского края было найдено девять фрагментарных черепов северных кожанков с явными следами наличия у них верхних малых предкоренных. Еще один экземпляр с необычной зубной формулой был обнаружен в коллекции Зоологического музея Московского государственного университета. Наличие малых предкоренных зубов, по крайней мере, у части особей представляет собой примитивную черту, противопоставляющуюE. nilssoni прочим более продвинутым видам рода.
\end{abstract}

КЛЮЧЕВЫЕ СЛОВА: Eptesicus, северный кожанок, зубная формула, малый предкоренной зуб, пещерные отложения.

\section{Introduction}

The number of premolars and degree of their reduction are commonly used as genus- or species-specific diagnostic characters for Vespertilionid bats (Bobrinskii et al., 1965; Tate, 1942; Corbet \& Hill, 1992; Pavlinov et al., 1995; Borisenko \& Kruskop, 2003; Smith \& Xie, 2008). Because the reduction of the number of teeth occurred independently in different evolutionary lineages of vespertilionids (Menu, 1987), the value of this character complex in phylogenetic reconstructions is doubtful. However, dental formulas can still be instrumental in characterizing certain genera. In particular, the genus Eptesicus (sensu Simmons, 2005 ) is defined by the constant absence of both small upper premolars (P2 and P3) (Corbet \& Hill, 1992) and, until recently, no exceptions to this were documented.
A recent excavation of the subfossil material from the Upper Pleistocene and Holocene cave deposits in the western Ural Mountains recovered numerous bat skeletal fragments, including many skulls of the northern bat, Eptesicus nilssoni. Amongst these remains, several skulls were found possessing well-developed alveoli of the small upper premolars in one or both sides of upper jaws. One additional skull of E. nilssoni with the same archaic feature was later found in the collection of the Zoological Museum of Moscow State University. This study aims to describe our unusual findings.

\section{Material and methods}

Subfossil bat remains were found in deep parts of the four natural caves situated in Alexandrovsk District, Perm' Territory, about 15-20 km north-east from the town of Yayva, between villages Skopkortnaya 

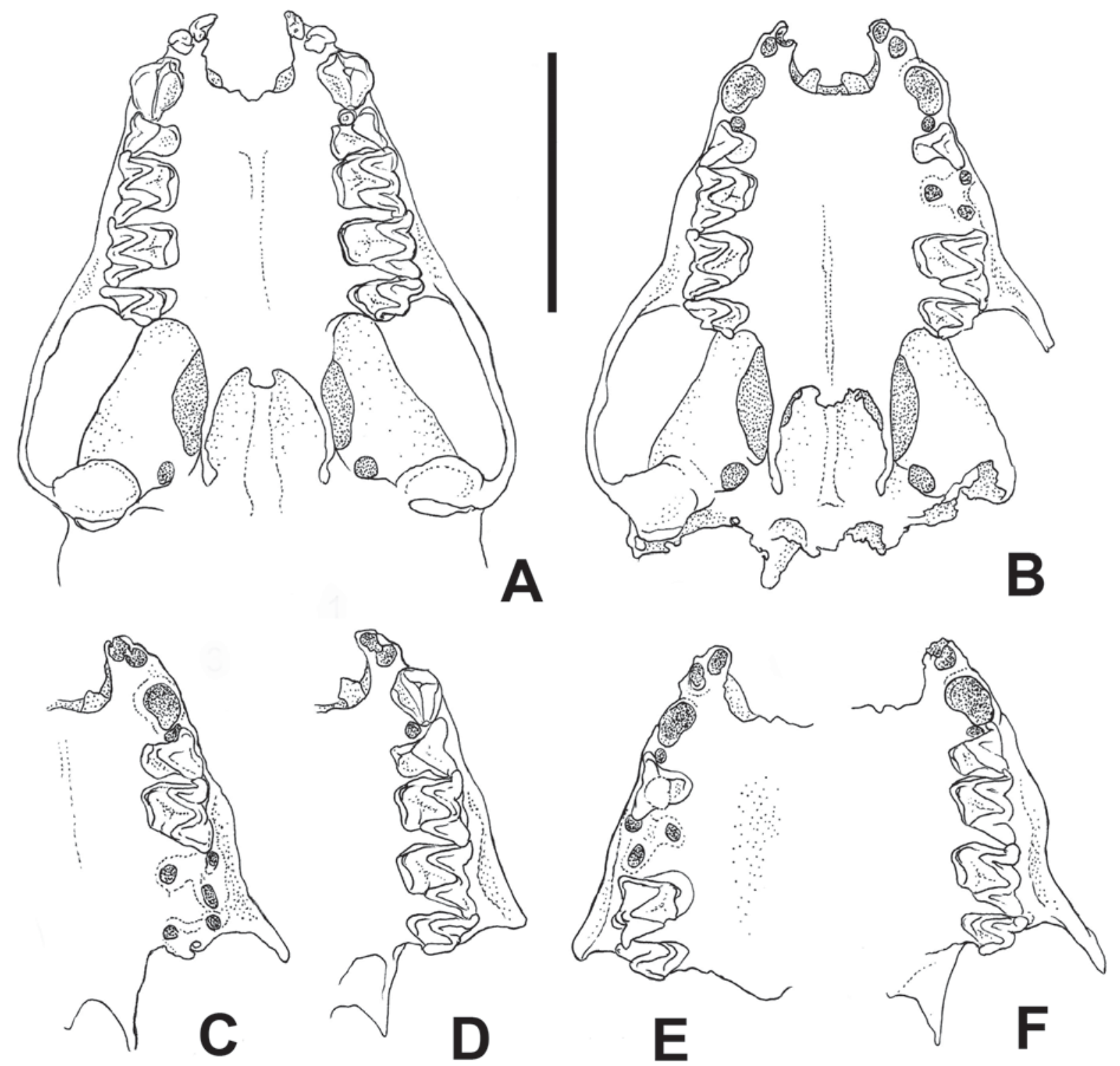

Figure 1. Upper jaws of Eptesicus nilssoni with traces of the small upper premolar (P2): A — adult male, captured in Nizhny Novgorod Region, with P2 in the left toothrow (ZMMU S-162550); B-F - premolar alveoli in subfossil skulls from Perm' Territory: E and F - P2 present only in one side (right and left, respectively, as shown), B, C and D - P2 positioned symmetrically of (for C and D only left jaws shown). Scale bar equals $5 \mathrm{~mm}$.

$\left(59.383^{\circ} \mathrm{N}, 57.818^{\circ} \mathrm{E}\right)$ and Kamen' $\left(59.491^{\circ} \mathrm{N}\right.$, $\left.57.447^{\circ} \mathrm{E}\right)$. The age of these deposits as determined by radiocarbon dating is $3628 \pm 86$ years for Bolshaya Mahnevskaya Cave (layer 1.40-1.47 m), $6121 \pm 127$ for Mahnevskaya Ledyanaya Cave (both analysis were made in the A.N. Severtsov Institute of Ecology and Evolution), $16470 \pm 560$ years (upper part of bone containing layer) for Tain Cave (analysis was made in Siberian brunch of Russian Academy of Sciences); Sokol'ya Cave (layer 0,0-0,35 m) was not dated yet, but presumably belong to the Late Holocene.

Subfossil remains of $E$. nilssoni were found in association with at least five other bat species: Myotis brandtii, M. mystacinus, $M$. daubentonii, M. dasycneme and Plecotus auritus, however, they dominate in proportion. The number of identified E. nilssoni remains totals 664 (14 in Sokol'ya Cave, 11 in Tain Cave, 69 in Mahnevskaya Ledyanaya Cave, and 570 in Bolshaya Mahnevskaya Cave). Identification of excavated skull fragments was made based on published identification manuals and comparison with extant bat skulls preserved in the collection of the Zoological Museum of Moscow University (ZMMU). All subfossil material is housed at the Laboratory of Historical Ecology, Institute of Plant and Animal Ecology, Ural Branch, Russian Academy of Sciences. 


\section{Results and discussion}

A total of nine Eptesicus skulls with P2 alveoli were found in all four caves: six in Bolshaya Mahnevskaya Cave and one in each of the remainder caves. Alveoli of P2 in two of these specimens were found on the left side only (Fig. 1F); in one case alveolus of P2 could be seen only on the right side (Fig. 1E); in four cases the position of the alveoli is symmetrical. Only one side of the rostral fragments was retained in two cases. In most specimens the alveolus of P2 was visibly displaced internally from the median of the toothrow. In these cases the canine and P4 were observed to be or extrapolated to have been in close contact, which is typical for Eptesicus. However, in four specimens the displacement of P2 alveolus was minimal (Fig. 1B, C), suggesting that the small premolar may have been visible from the buccal side of the toothrow. This corresponds to a stage of its reduction found in some recent Pipistrellus and Hypsugo.

During the comparison of our subfossil material with the ZMMU collection, an additional anomalous skull was found: an adult male captured in the Ichalki protected area, Perevoz District of the Nizhny Novgorod Region. This specimen possesses a small but well developed P2 in its left tooth row (Fig. 1A). The tooth is conical in shape, rounded in occlusal view, about 0.3 $\mathrm{mm}$ in diameter and is almost identical to the same teeth in Arielulus and Hypsugo.

Members of the genus Eptesicus sensu Simmons (2005), i.e. including "serotinus" and "fuscus" species groups with their most possible relatives, are generally characterized by having only one premolar (P4) in each upper tooth row (Dobson, 1876; Corbet \& Hill, 1992). By contrast, some other taxonomically proximate genera possess upper small premolars as a facultative feature subject to intraspecific variation between populations or even between individuals within one population. These genera include Hypsugo, Arielulus, and Neoromicia. The latter two were sometimes synonymized with Eptesicus (Koopman, 1993; Volleth \& Heller, 1994), although recent molecular data (Hoofer \& Bussche, 2003), confirm their valid generic status. Within Eptesicus proper, no small upper premolars were described, even as rudiments (Hill \& Harrison, 1987; Corbet \& Hill, 1992). The only alternate idea was expressed by Menu (1987), however without explanation of any concrete examples. Amongst taxa closely related to Eptesicus based on DNA sequence data, only Ia io has greatly reduced small upper premolars (Bates \& Harrison, 1997).

The proportion of northern bats with anomalous dental formula averaged ca. 1.4 percent amongst subfossil material (1.1-9\% for different caves). A comparable result was obtained for extant material — about $1.5 \%$ ( 1 out of 67 processed). This leads to suppose that the presence of $\mathrm{P} 2$ is a very rare but not an extraordinary case for E. nilssoni. This, combined with other archaic morphological traits, makes this species unique within its genus and challenges its sister position to $E$. serotinus inferred from mtDNA (Mayer \& Helversen, 2001), calling for a more thorough revision.

ACKNOWLEDGEMENTS. Authors would like to express their gratitude to N.G. Smirnov, P.A. Kosintzev (Institute of Plant and Animal Ecology, Ural Branch of RAS), A.B. Savinetskii, B.F. Hasanov (A.N. Severtsov Institute of Ecology and Evolution) and L.A. Orlova (Institute of Geology, Siberian brunch of RAS) for organizing and implementation of the radiocarbon dating of osteological samples. The expeditions of the first author to the caves of the Perm' Territory were organized with the essential help of I.G. Ponosov, N.A. Fadeev, A.A. Vorobiev, and S.V. Miheev. Collecting of the subfossil material was held under financial support of the Russian Fund for Basic Research (grant ${ }^{1}$ 0804-00663). We also express our special thanks to A.V. Borisenko for his invaluable help in editing the manuscript.

\section{References}

Bates P.J.J. \& Harrison D.L. 1997. Bats of the Indian subcontinent. Sevenoaks: Harrison Zoological Museum. 258 p.

Bobrinskii N.A., Kuznetsov B.A. \& Kuzyakin A.P. 1965. [Identification guide to the Mammals of USSR.] Moscow: Prosvescheniye. 382 p. [in Russian].

Borisenko A.V. \& Kruskop S.V. 2003. Bats of Vietnam and adjacent territories. An identification manual. Moscow: Geos. 203 p.

Corbet G.B. \& Hill J.E. 1992. The Mammals of the Indomalayan Region. Oxford: Oxford University Press. 488 p.

Dobson G.E. 1876. Monograph of the Asiatic Chiroptera. London: Taylor and Francis. 228 p.

Hill J.E. \& Harrison D.L. 1987. The baculum in Vespertilioninae (Chiroptera: Vespertilionidae) with a systematic review, a synopsis of Pipistrellus and Eptesicus, and the description of a new genus and subgenus // Bulletin of the British Museum (Natural History), Zoology Series. Vol.52. No.7. P.225-305.

Hoofer S.R. \& Bussche R.A., van den. 2003. Molecular phylogenetics of the chiropteran family Vespertilionidae // Acta Chiropterologica. Vol.5 supplement. P.1-63.

Koopman K.F. 1993. Order Chiroptera // Wilson D.E. \& Reeder D.M. (eds.). Mammal Species of the World, a Taxonomic and Geographic Reference, Second Edition. Washington, D.C.: Smithsonian Institution Press. P.137-241.

Mayer F. \& Helversen O.v. 2001. Cryptic diversity in European bats // Proceedings of the Royal Society B: Biological Sciences. Vol.268. No.1478. P.1825-1832.

Menu H. 1987. Morphotypes dentaires actuels et fossiles des chiroptères // Palaeovertebrata. Vol.17. P.77-150.

Pavlinov I.Y., Borisenko A.V., Kruskop S.V. \& Yahontov E.L. 1995. [Mammals of Eurasia. II. Non-Rodentia.] Moskva: Izdatel'stvo Moskovskogo Universiteta. 336 p. [in Russian].

Simmons N.B. 2005. Order Chiroptera // Wilson D.E. \& Reeder D.M. (eds.). Mammal Species of the World, a Taxonomic and Geographic Reference, Third Edition. Baltimore: Johns Hopkins University Press. P.312-529. Smith A.T. \& Xie Y. (eds.). 2008. A guide to the Mammals 
of China. Princeton: Princeton University Press. 544 p. Tate G.H.H. 1942. Review of the Vespertilionine bats, with special attention to genera and species of the Archbold collections // Bulletin of the American Museum of Natural History. Vol.80. No.7. P.221-297.
Volleth M. \& Heller K.G. 1994. Phylogenetic relationships of vespertilionid genera (Mammalia: Chiroptera) as revealed by karyological analysis // Zeitschrift für Zoologische Systematik und Evolutionsforschung. Vol.32. P.11-34. 